\title{
The impact of bridges on spatial transformation of urban pattern: The case of Golden Horn, Istanbul
}

\author{
Demet Yesiltepe, Ayse Sema Kubat \\ Istanbul Technical University, Faculty of Architecture, Department of City and Regional \\ Planning. Turkey \\ E-mail: demetyesiltepe@gmail.com,kubat@itu.edu.tr
}

\begin{abstract}
Transportation projects especially subways, bridges and new transportation modes gained importance in Istanbul in the last decades. The Golden Horn Metro Bridge, which connects two parts of the European side of Istanbul and has a station on the bridge, has caused criticisms not just because of having these unique characteristics but also because of the effects of the bridge on the silhouette of Historical Peninsula. The main aim of this paper is to analyze the impact of bridges on urban pattern and to explore the different influences of metro and vehicular bridges. Within this scope, three bridges located over the Golden Horn, which created connections between historical site of Istanbul and the newly developed CBD, are chosen as case study. Areas within $1 \mathrm{~km}$ zones around the bridges are analysed separately, and the urban pattern (street pattern, block size, building data) is investigated comparatively through GIS. The layers of the past geographies (Historical GIS) and the Space Syntax (angular segment based integration and choice) analyses are conducted for demonstrating spatial changes. The findings indicate that the study area has transformed into more divided streets and urban blocks and the number of buildings increased through time. Moreover, it is observed that the metro-rail bridge system has less impact on urban pattern. This study contributes to urban planning/design not only by analysing comparatively the transformation of the urban pattern during the pre- and post-construction processes of the bridges but also by evaluating the impact of the bridges through a quantitative and innovative method.
\end{abstract}

Keywords: Urban pattern, transportation projects, the Golden Horn Metro Bridge, Istanbul

\section{Introduction}

The Golden Horn region of Istanbul constitutes a significant historical part of the city and this area has changed dramatically during its history. The bridges which have been constructed along the Golden Horn are essential examples of these changes (Figure 1). Due to the effect of these bridges, the form of the neighbourhoods on the Golden Horn has changed, and by examining this change, this paper analyses the major influences of bridges on the urban pattern of cities.
The main purpose of this study is to analyse the influence of bridges on urban pattern and to explore the different effects of metro and vehicular bridges. The goals of this paper are:

I. To explore the pattern of settlements of the Golden Horn and determine its level of transformation

II. To analyse the spatial structure of the area by using Historical GIS method

III. To discover the different effects of vehicular-pedestrian bridges and metropedestrian bridge

IV. To make a mathematical comparison also by using Space Syntax methodology. 
Urban morphology is an approach which is used to conceive the physical form. This concept explores how towns have grown and developed through small scale analyses of buildings, plots and streets, and also macro scale studies (Larkham 2005). Buildings, gardens, parks, streets are the main elements of any morphological analysis; thus, they have dynamic relationships: each one shapes the others and is also influenced by them (Moudon 1997).

It is believed that cities can be read according to their physical form. In addition to this, there is an acknowledgement that morphological analysis is based on three principles:

1. Urban form can be defined by three elements: the buildings and their open spaces, the plots/ lots and the streets,

2. Urban form can be understood from the building or lot, the street, the city, and the region,

3. Urban form can be understood historically through the transformation and replacement it has undergone (Moudon 1997).

As a part of this study, street patterns, buildings and urban blocks have been analyzed not only to explore the urban form, but also to discover the transformations it has undergone. Moreover, space syntax methodology is also adapted to this paper. This methodology is developed by a team led by Bill Hillier (1996). Space Syntax is essential for urban planning and design studies as it gives consistent results based on the mathematical data created according to the open spaces within cities. This methodology provides evidence-based learning by creating a framework that allows comparisons between settlements to be made(Peponis 1990).

\section{Methodology}

Within the scope of this paper, three bridges located over the Golden Horn, which created links between historical site of İstanbul and the newly developed CBD, are chosen as study area. Three bridges which span the Golden Horn; the Atatürk, Galata and Golden Horn Metro bridges were selected to facilitate an analysis of the influence of bridges on settlements. Areas within $1 \mathrm{~km}$ zones around the bridges are analysed separately, and the urban pattern (street pattern, block size, building data) is investigated comparatively through GIS. The layers of the past geographies (Historical GIS) and the Space Syntax (angular segment based integration and choice) analyses are conducted for demonstrating spatial changes.

Empirical evidence is used to determine $1 \mathrm{~km}$ as a distance that people can walk (Lee and Moudon 2006). To determine the specific study area, $1 \mathrm{~km}$ zones around the bridges were created and the mathematical data inside these buffers is analysed separately for three bridges (Figure 2).

The neighbourhoods around the bridges were selected as a study area due to the historical processes they have undergone, and also due to the bridges themselves as they were built during different time periods. There are many important examples of Ottoman urban layouts in the study area. While one side of the area is historic, the other side is connected to more developed areas. As a part of this study, not only the pre-, post- construction process of bridges but also two-time periods, which urban pattern changed dramatically, were also examined. During the first - 1922 - the Islamic city image changed to that of a more cosmopolitan city; the organic pattern started to shift toward a grid pattern and the Republic was about to be proclaimed. During the second - 1996 - several planning decisions were implemented in the study area, thus the patterns of the settlements around the bridges were changed.

On the other hand, to discover the transformations of street patterns, buildings and urban blocks, Historical GIS methodology is adapted to the study. A Geographic Information System (GIS) links locations and their attributes so that they can be analyzed, whether by their geographical characteristics or factors such as distance, location, or physical characteristics. The main organization principle of GIS is based on location, which is encoded as geographical coordinates. With the location data established, it then becomes 


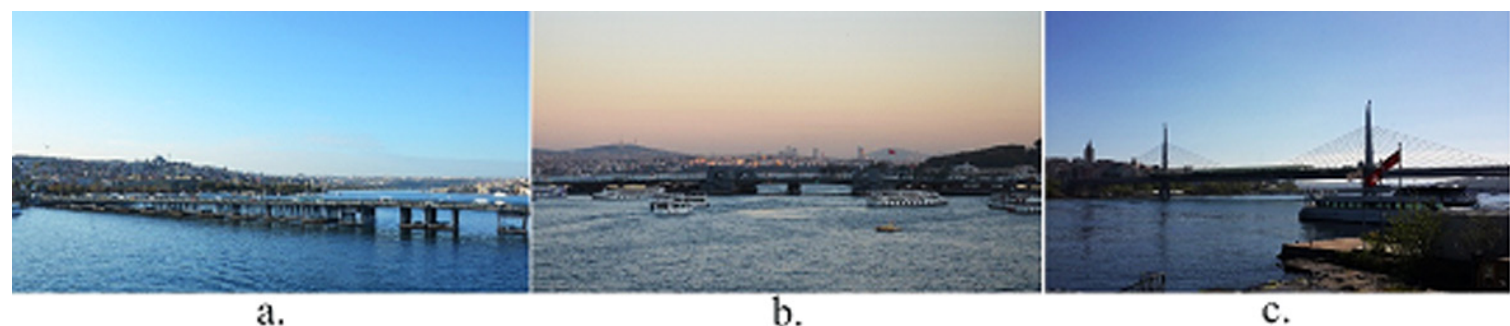

a.

b.

c.

Figure 1. The bridges located over the Golden Horn (a. Ataturk Bridge, b. Galata Bridge, c. the Golden Horn Metro Bridge)

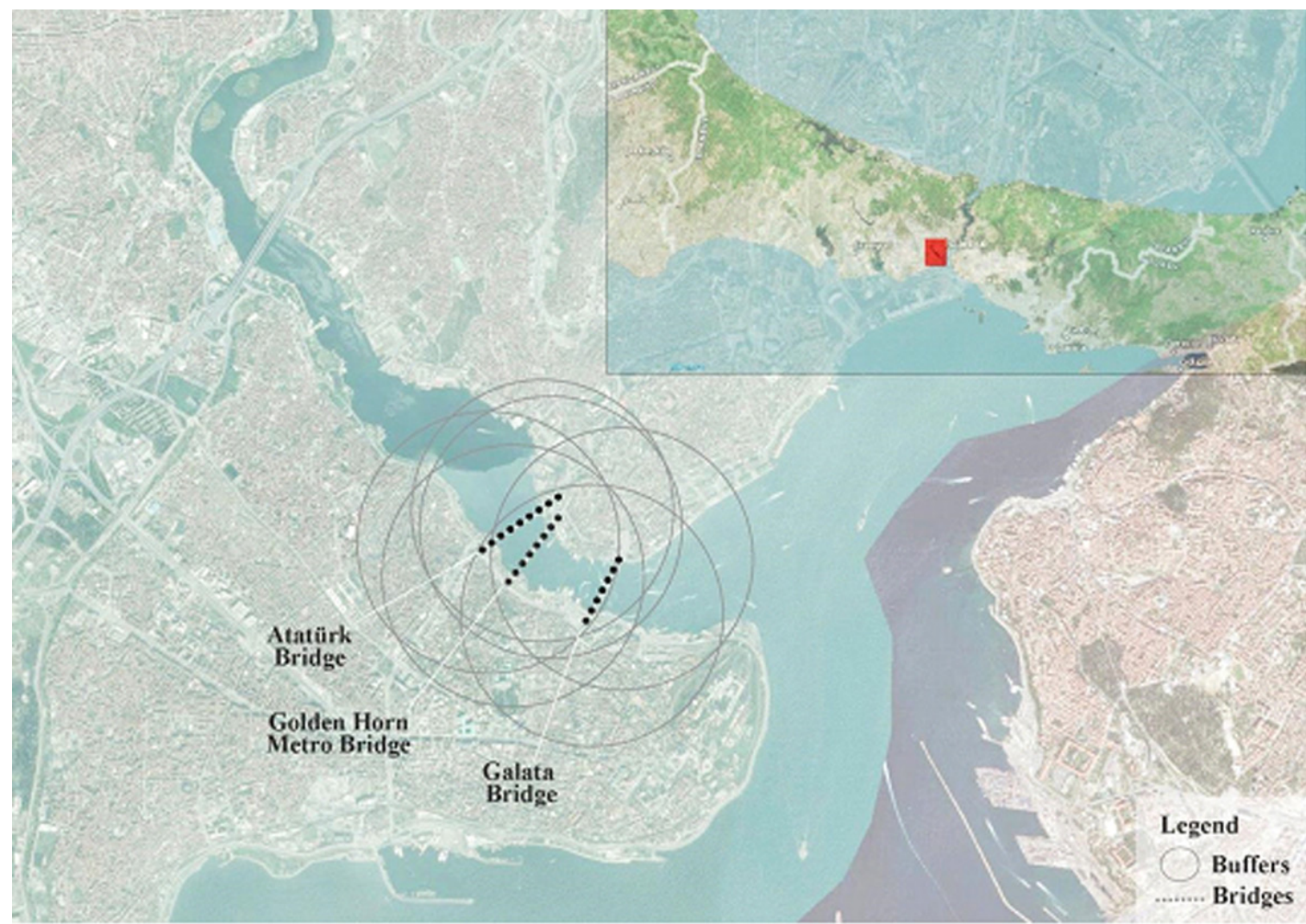

Figure 2. Location of the bridges and the case area

a powerful tool for the analysis and integration of other variables (Knowles, 2002).

There are several advantages of Historical GIS; first, the spatial data reveals where the data is located and thus, it can be used for integrating any data which seems incompatible. Secondly, Historical GIS allows data to be visualized by using maps and other techniques such as virtual landscapes and animation. Thirdly, GIS allows different forms of spatial analysis to be made where the coordinate locations of the features under examination are a specific part of the analysis (Gregory \& Healey, 2007; Gregory et al., 2001). Moreover, once a historical map is added to GIS, the information it contains can be extracted, analyzed and compared with other data (Knowles \& Hillier, 2008). Therefore, the data about street pattern, urban blocks and buildings isgenerated for different time periods by using this methodology (Figure 3 ).

Moreover, angular segment based integration and choice values are also calculated through the use of Depthmap10 software. Choice can be defined as the possibility for each segment to be selected by pedestrians as the shortest route. A choice analysis means the "through movement" potential of each segment in a system (Al Sayed et al., 2014).Integration is 


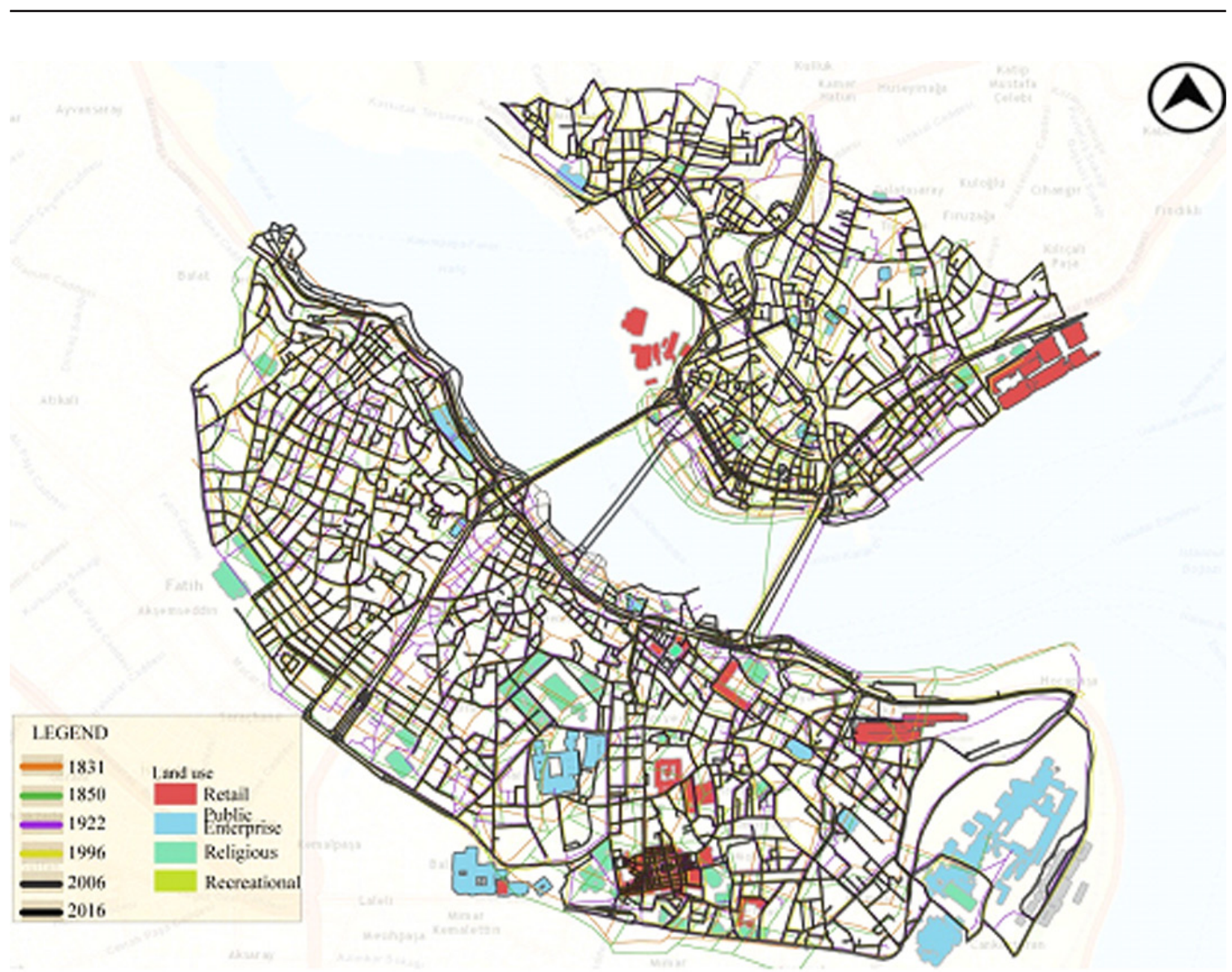

Figure 3. Historical layers of the Golden Horn

defined as the distance of each segment to all other segments in a system (Hillier et al., 2012). Therefore, it can be said that while a choice analysis examines the through movement potential, an integration analysis examines its "to movement" potential of a given system. Integration shows the degree to which a line is more integrated, or segregated, from a system as a whole (Jacoby, 2006).

\section{Analysis \\ Historical Process}

Historical background of the bridges over the Golden Horn dates to 1930s. In 1836, the first historically-verifiable bridge, Unkapanı (new Atatürk Bridge) bridge was built across the Golden Horn. After this period, because of the growing population and new palace for the Sultan, a second bridge was needed. Therefore, the "Cisr-iCedid" bridge, now known as the Galata Bridge, was built in 1845 (Cekmis Gorgulu and Hacihasanoglu 2012).
On the other hand, the construction process of the last bridge, the Golden Horn Metro Bridge, first started with an announcement by the mayor of metropolitan Istanbul, Kadir Topbaş, in 2004 and the project was approved in 2009 by the Conservation Board. Although the Historical Peninsula, where an abutment of the bridge is located, has been on the World Heritage Site list since 1985, the bridge project was not reported to UNESCO (Vardar 2014). When the construction of the project began in 2009, UNESCO stated that this project would damage the silhouette of the Historical Peninsula and warned that the area could be added to the World Heritage in Danger category (Bilgehan 2015). After this warning, the project was revised and the height was decreased from 82 meters to 65 meters and construction work was halted until 2011 (Vardar 2014). In 2012, the revised design of the project was approved and the bridge eventually entered service in

February 2014. 


\section{Spatial and Syntactic Changes}

Spatial changes before and after the construction of the Unkapanı (Atatürk) Bridge

At the beginning of 1830 's, the Historical Peninsula was the centre of the settlement and the Galata region was limited by its old borders. The street pattern was usually organic, except at the north side of the Golden Horn. Additionally, Topkap 1 Palace, the Suleymaniye and Yeni Valide mosques, the Grand Bazaar and the other commercial buildings and large mosques were the most prominent structures of the period. During this period, the number of street segments totalled 272 and average number of buildings totalled 148. Moreover, the average area of urban blocks was 29853 square meters (Table 1).

After the construction of the first bridge, the data shows that the number of street segments increased to 303 and the average area of urban blocks decreased to 25301 square meters. Furthermore, the average length of streets declined from 151 meters to 140 meters and the average area of buildings decreased from 412 square meters to 385 square meters. To conclude, the area around the first bridge transformed into more divided streets and urban blocks after the construction of the Unkapanı Bridge.

On the other hand, after the construction of the first bridge, the street network configuration of the study area underwent some changes too (Table 2). As shown in the table, the choice (n) value increased from 3.73 to 4.15 and the choice within 400 meters increased from 2.14 to 2.39 . In addition, integration (n) value increased from 2.05 to 2.28 in this time period.

Spatial changes before and after the construction of the Cisr-iCedid (Galata)Bridge After the construction of the second bridge in 1845 , the number of street segments rose from 277 to 287 and the number of buildings increased from 314 to 365 around the bridge. Moreover, average area of buildings decreased from 545 square meters to 482 square meters (Table 3).

On the other hand, it is observed that $\ln$ (n) increased from 2.28 to 2.34 and $\ln (\mathrm{r} 3)$ increased from 1.79 to 1.94. And finally, connectivity increased from 0.48 to 0.52 after the construction of the second bridge (Table 4). Therefore, it is possible to state that after the construction of the second bridge, the area become more accessible and connected.

\section{Spatial changes during the 20th Century}

During the 20th century, there were many different processes underway in the study area. Therefore, it is constructive to conduct an analysis across two different time periods. First, in 1922, the Republic was about to be proclaimed and a tram lane was added to the Galata Bridge. The most important buildings were the Sirkeci railway terminal (on the Historical Peninsula), two hospitals (Beyoğlu and Sankt Georgs) and the town hall (located in Galata) in this time period. Additionally, after the establishment of the Republic of Turkey, Topkap1 Palace was transformed into a museum at the date April 1924 and it was also the first museum of the Republic of Turkey. Ministry of war was transformed into a university building in 1923.

In 1933, after the proclamation of the Republic, three different urban planners were invited to the city and a new planning approach was developed. One of the most important events of the period was the invitation extended to Prost. His plans affected Istanbul in a number of different ways - in particular, a scheme to create different functional zones for different activities. One consequence of this was the relocation of all industrial facilities to the Golden Horn, which affected the area in a negative way as the shore became heavily polluted and the area soon fell into ruin. However, Prost was also responsible for limiting the height of buildings, which successfully preserved the silhouette of the Golden Horn (Kuban, 1996).

Under the government of Prime Minister Adnan Menderes between 1950 and 1960, the whole city underwent some changes. These included the introduction of wide boulevards, which Menderes took from the examples of European countries. The road between Unkapanı and Yenikap1 (which is located on the south side of the Atatürk Bridge) was widened. From Galata to Dolmabahçe, from Karaköy to 
Azapkap1 and between the two bridges over the Golden Horn, more new boulevards were built (Kuban, 1996).

During the 1980s, the city underwent many economic, social and political transformations. A new master plan was created, and there was also a plan to remove the industrial areas from the shores of the Golden Horn. The planned demolitions, which are now remembered as "Dalan Operations" (after Bedrettin Dalan, the mayor at the time), were given the goahead, and more than 4000 buildings up to 50-100 meters inland of the Golden Horn shoreline were expropriated. 696 factories and 2020 offices were demolished and relocated. Furthermore, the shoreline of the

Golden Horn (representing about a million square kilometres) was transformed into parks and gardens (Erbey, 2009).

By the beginning of the 21st century, communication within the core of Istanbul was improved. The main aim of this period was to provide an uninterrupted communication network across the Historical Peninsula by creating new arteries so that these could make connections between the heart of the city (the commercial center) and the Byzantine gates (Kubat, 1999).

Spatial changes before and after the construction of the Golden Horn Metro Bridge In 2016, after the construction of the last bridge, the number of street segments increased from 17168 to 17507 and the average length of street segments increased from 6,48 to 6,53 . The number of buildings increased from 269 to 298 and the average area of buildings raise from 431 square meters to 558 square meters (Table 5). The study area now contained Istanbul Ticaret University and Kadir Has University; thus, these buildings can be thought as the most significant reason for the changes in the number of buildings and the average area of the buildings.

After the construction of the last bridge, the Golden Horn Metro Bridge, a very slight change in syntactic values around the bridge was observed. It is determined that the values of choice (n) decreased and choice within 400 meters and integration (r3) increased slightly while choice within 800 meters and $\ln (n)$ remained stable (Table 6).

Table 1: Spatial changes around the Unkapanı Bridge

\begin{tabular}{|r|r|r|r|r|r|}
\hline Years & $\begin{array}{r}\text { Average } \\
\text { building area } \\
(\mathrm{m} 2)\end{array}$ & $\begin{array}{r}\text { Number of } \\
\text { buildings }\end{array}$ & $\begin{array}{r}\text { Average street } \\
\text { length }\end{array}$ & $\begin{array}{r}\text { Number of } \\
\text { streets }\end{array}$ & $\begin{array}{r}\text { Average area of } \\
\text { urban blocks (m2) }\end{array}$ \\
\hline 1831 & 412,207 & 148 & 151,139 & 272 & 29853,188 \\
\hline 1838 & 385,346 & 145 & 140,980 & 303 & 25301,827 \\
\hline
\end{tabular}

Table 2: Syntactic changes around the Unkapanı Bridge

\begin{tabular}{|c|c|c|c|c|c|c|}
\hline Years & Connectivity & $\begin{array}{r}\text { Choice } \\
\text { (n) }\end{array}$ & $\begin{array}{r}\text { Choice } 400 \\
\text { metric } \\
\end{array}$ & $\begin{array}{r}\text { Choice } 800 \mathrm{~m} \\
\text { etric }\end{array}$ & $\operatorname{Ln}(\mathrm{n})$ & $\operatorname{Ln}(\mathrm{r} 3)$ \\
\hline 1831 & 0.526 & 3.739 & 2.142 & 2.905 & 2.059 & 1.813 \\
\hline 1838 & 0.491 & 4.159 & 2.399 & 3.145 & 2.286 & 1.779 \\
\hline
\end{tabular}

Table 3: Spatial changes around the Galata Bridge

\begin{tabular}{|r|r|r|r|r|r|}
\hline Years & $\begin{array}{r}\text { Average } \\
\text { building area } \\
(\mathrm{m} 2)\end{array}$ & $\begin{array}{r}\text { Number of } \\
\text { buildings }\end{array}$ & $\begin{array}{r}\text { Average street } \\
\text { length }\end{array}$ & $\begin{array}{r}\text { Number of } \\
\text { streets }\end{array}$ & $\begin{array}{r}\text { Average area of } \\
\text { urban blocks (m2) }\end{array}$ \\
\hline 1838 & 545,773 & 314 & 146,801 & 277 & 24897,113 \\
\hline 1850 & 482,986 & 365 & 146,411 & 287 & 24702,920 \\
\hline
\end{tabular}




\section{Conclusion}

Intelligibility is a value which is derived from the correlation between connectivity and global integration. A high correlation between two factors means that the spatial structure is intelligible, and low correlation means that the spatial structure is not intelligible. Kubat(1997), discovered that the intelligibility value of the Anatolian towns she analyzed was 0.350 , while that of the Islington area of London has been reported at 0.61-0.26 (Hillier 1989), and that of Athens has been reported at 0.790 (Peponis et al. 1989).

The intelligibility values of the areas around the three bridges are higher compared with both Kubat's analyses and the overall values reported in 2016 (Table 7). Thus, when considering whole case area, the spatial pattern around the bridges is more intelligible.

As result of these analyses, it is possible to state that the study area has transformed into more divided streets and urban blocks, and the number of buildings increased over these periods. Although it is not possible to claim that the bridges are the only factors behind these changes, it can be stated that the bridges have created more integrated and accessible spaces. Therefore, as planned, Galata and Karaköy regions have become more accessible and more preferred areas; thus, new functions and buildings have been constructed.

Table 4: Syntactic changes around the Galata Bridge

\begin{tabular}{|r|r|r|r|r|r|r|}
\hline Years & Connectivity & $\begin{array}{r}\text { Choice } \\
(\mathrm{n})\end{array}$ & $\begin{array}{r}\text { Choice400m } \\
\text { etric }\end{array}$ & Choice800metric & $\operatorname{Ln}(\mathrm{n})$ & $\operatorname{Ln}(\mathrm{r} 3)$ \\
\hline 1838 & 0.488 & 4.199 & 2.388 & 3.133 & 2.286 & 1.792 \\
\hline 1850 & 0.522 & 4.192 & 2.304 & 3.045 & 2.346 & 1.940 \\
\hline
\end{tabular}

Table 5: Spatial changes around the Golden Horn Metro Bridge

\begin{tabular}{|r|r|r|r|r|r|}
\hline Years & $\begin{array}{r}\text { Average } \\
\text { building area } \\
(\mathrm{m} 2)\end{array}$ & $\begin{array}{r}\text { Number of } \\
\text { buildings }\end{array}$ & $\begin{array}{r}\text { Average street } \\
\text { length }\end{array}$ & $\begin{array}{r}\text { Number of } \\
\text { streets }\end{array}$ & $\begin{array}{r}\text { Average area of } \\
\text { urban blocks (m2) }\end{array}$ \\
\hline 2006 & 431,959 & 269 & 6,487 & 17168 & 4357,475 \\
\hline 2016 & 558,941 & 298 & 6,532 & 17507 & 4493,386 \\
\hline
\end{tabular}

Table 6: Syntactic changes around the Golden Horn Metro Bridge

\begin{tabular}{|r|r|r|r|r|r|r|}
\hline Years & Connectivity & $\begin{array}{r}\text { Choice } \\
\text { (n) }\end{array}$ & Choice400metric & Choice800metric & $\operatorname{Ln}(\mathrm{n})$ & $\operatorname{Ln}(\mathrm{r} 3)$ \\
\hline 2006 & 0.370 & 7.466 & 7.051 & 7.070 & 3.644 & 3.806 \\
\hline 2016 & 0.369 & 7.465 & 7.052 & 7.070 & 3.644 & 3.807 \\
\hline
\end{tabular}

Table 7:Correlation of bivariate connectivity and integration(n) data for three bridges in 2016

\begin{tabular}{|r|r|r|r|}
\hline Bridge & Atatürk Bridge & Galata Bridge & Golden Horn Metro Bridge \\
\hline $\mathrm{R}^{2}$ & 0.408 & 0.459 & 0.413 \\
\hline Significance & 0.01 & 0.01 & 0.01 \\
\hline $\mathrm{N}$ & 16936 & 16132 & 16684 \\
\hline
\end{tabular}

** Correlation is sionificant at the 001 level (2-tailed) 
This study is an attempt to contribute to the literature by explaining the influences of bridges on urban morphological characteristics and street network configurations. Furthermore, the metro bridge-rail system of the Golden Horn Metro Bridge has had less impact on the pattern of the settlements when it is compared with the impact of the vehicular bridges. The primary reason for these lower values is that there is no distinct, continuous pedestrian route in the north-west direction. However, just as with the Galata and Atatürk bridges, it is expected that with some new planning decisions (new routes connected to the main sidewalks and new functions around the Golden Horn Metro Bridge), the settlements around the bridge will become more accessible and integrated spaces.

\section{References}

Al_Sayed, K., Turner, A., Hillier, B., Iida, S., and Penn, A. (2014) 'Space syntax methodology. A teaching textbook for the MSc Spatial Design: Architecture \& Cities.' Bartlett School of Architecture, UCL: London.

Bilgehan, Z. (2015) 'UNESCO Artık Daha Anlayışl1.' Retrieved (http://www. hurriyet.com.tr/unesco-artik-dahaanlayisli-28179189).

Cekmis Gorgulu, A., and Hacihasanoglu, I. (2012) 'Water Crossing Utopias of Istanbul : Past and Future.' Istanbul Technical University, Faculty of Architecture 9(2):6788.

Erbey, D. E. (2009) 'Haliç ' te Dönü ş üm ve Tarihsel Süreklilik.' Osmanlı Bankası Arşiv ve Araştırma Merkezi

Gregory, I. N., Kemp, K. K., and Mostern, R. (2001) 'Geographical Information and historical research: Current progress and future directions.' History and Computing, 13(1), 7- 23.

Gregory, I. N., and Healey, R. G. (2007) 'Historical GIS: Structuring, mapping and analysing geographies of the past.' Progress in Human Geography, 31(5), 638-653.

Hillier, B. (1989) 'The Architecture of the Urban Object.' Ekistics 56(334/35):5-21.

Hillier, B. (1996) 'Space Is the Machine: A
Configurational Theory of Architecture.' edited by Space Syntax. London, United Kingdom: Cambridge University Press. Retrieved February 3, 2015 (http://discovery. ucl.ac.uk/3881/1/SITM.pdf).

Hillier, W. R. G., Yang, T., and Turner, A. (2012) 'Normalising least angle choice in Depthmap-and how it opens up new perspectives on the global and local analysis of city space.' Journal of Space syntax, 3(2), 155-193.

Jacoby, K. (2006) 'What is space syntax: Does the urban form of the city affect the level of burglary and crime.' Royal Institute of Architecture Stockholm.

Knowles, A. K. (2002) 'Past Time, Past Place: GIS for History.'

Knowles, A. K., and Hillier, A. (2008) 'Placing history: how maps, spatial data, and GIS are changing historical scholarship.' ESRI, Inc..

Kuban, D. (1996) 'İstanbul Bir Kent Tarihi.' Türkiye Ekonomik ve Toplumsal Tarih Vakfi, İstanbul.

Kubat, A. S. (1997). The Morphological Characteristics of Anatolian Fortified Towns. Environment and Planning B: Planning and Design 24(1):95-123.

Kubat, A. S. (1999) 'The morphological history of Istanbul.' Urban Morphology, $3(1), 28-41$.

Larkham, P. J. (2005) 'Understanding Urban Form?' Urban Design 93:22-24.

Lee, C., and Moudon, A. V. (2006) 'Correlates of Walking for Transportation or Recreation Purposes.' Journal of Physical Activity \& Health 3:77-98. Retrieved (http://216.92.169.205/alr/alr/files/jpah_6_ lee.pdf).

Moudon, A. V. (1997) 'Urban Morphology as an Emerging Interdisciplinary Field.' Urban Morphology 1:3-10.

Peponis, J. (1990) 'Space Syntax.' Environment and Behavior 4(12):17-29.

Peponis, J., Hadjinikolaou, E., Livieratos,C., and Fatouros, D.(1989) 'The Spatial Core of Urban Culture.' Ekistics 56(334/335):4355.

Vardar, N. (2014) 'Tüm Itirazların Ardından Haliç Köprüsü.' Retrieved (http://bianet. org/bianet/toplum/153027-tum-itirazlarinardindan-halic-koprusu). 